\title{
COVID-19 Pandemic: Health Challenges and a Critical Study of the Structure of the Nigeria Economy
}

\section{Samuel Daniel Ugochukwu ${ }^{1}$, Ekene Samuel Odo ${ }^{2}$, Oluwatosin Miracle Atewologun ${ }^{3}$, Adetola Abiodun Adeyeye ${ }^{4}$, Tosin David Olaegbe ${ }^{5}$}

\author{
${ }^{1}$ Ebonyi State University \\ PMB 053, Abakaliki, Nigeria \\ ${ }^{2}$ Michael Okpara University of Agriculture, Umudike \\ PMB 7267, Umuahia Umudike, Abia State, Nigeria \\ ${ }^{3}$ Ladoke Akintola University of Technology \\ P. M. B 4000, Ogbomoso, Oyo State, Nigeria \\ ${ }^{4}$ Osun State University \\ Oke Bale Street, Area 210001, Osogbo \\ ${ }^{5}$ University of Ibadan \\ Oduduwa Road, 200132, Ibadan, Nigerian
}

DOI: $10.22178 /$ pos.76-4

JEL Classification: E31

Received 27.10.2021

Accepted 25.11.2021

Published online 30.11.2021

Corresponding Author:

Samuel Ugochukwu Daniel

samuelug01995@gmail.com

(c) 2021 The Authors. This

article is licensed under a

Creative Commons Attribution

4.0 License @) (1)

Abstract. Sub-Saharan Africa has been characterized as having a high prevalence of malaria and HIV. The present COVID-19 outbreak compounds and complicates Nigeria's health and socio-economic problems that require stringent public health measures, improved health facilities and achievable economic policies to tackle. The impact of COVID-19 on national economies depends on the level of preparedness and responsiveness to shocks. This perspective dissected the structure of the Nigerian economy and the effect of the pandemic on Nigeria's economy, having given mild health implications. The study adopted an exploratory research design and thus, relied on the past socio-economic situation in Nigeria to explain how Nigeria was affected by the pandemic. This perspective concludes that the socio-economic foundation in Nigeria is weak. These weak socio-economic settings have made the economy vulnerable to external and internal shocks. This study recommends that the Nigerian government provide adequate and internationally standard training facilities for her health workers and ensure that they are paid well and as when due. To build a resilient economy that can survive external and internal shocks, there is a need to diversify the economy's economic base fully. Alongside achieving economic diversification, there is the need to improve the existing agricultural-industrial link. The Central Bank should adopt effective monetary policy measures to facilitate credit to private sectors to promote investment in key sectors in the economy. There is a need to increase stimulus package for all industries and households to sustain and improve employment and consumption levels. There is a need to improve efficiency in government spending. The government should sincerely invest in infrastructures to reduce the cost burden on the private sector. Furthermore, there is a crucial need to increase government investment in the health and education sector to prepare the nation for any other health emergency and build its human capital.

Keywords: COVID-19; Health; Human Capital; Inflation; Unemployment; Exchange Rate.

\section{INTRODUCTION}

The global economy suffered due to the Covid2019 outbreak, and the post-pandemic economy is still in battle globally. Before the global Corona
Virus outbreak, Nigeria fought infectious diseases outbreaks such as Lassa fever, Yellow fever, acute hepatitis E, Meningococcal disease, Cholera, Wild polio, and Vaccine derived poliovirus type 2, and Acute fever and rash Syndrome. Nigeria has rec- 
orded commendable victories against Ebola Virus Disease (EVD), Monkeypox and Avian influenza; however, malaria remains a global health menace threatening public health in Nigeria before the Corona Virus (COVID-19) pandemic. Sub-Saharan Africa has been characterized as having a high prevalence of malaria and HIV [15, $20,48,30]$. The present COVID-19 outbreak compounds and complicates Nigeria's health and socio-economic problems that require stringent public health measures, improved health facilities and achievable economic policies to tackle. Recall that in December 2019, the World Health Organization (WHO) was alerted of clusters of pneumonia cases of unknown causes in Wuhan City (Hubei Province) of China. A novel strain of Corona Virus (SARS-CoV-2) was subsequently identified as the Chinese authorities' causative agent [49]. On the 30th of January 2020, WHO declared the Corona Virus outbreak as a Public Health Emergency of International Concern (PHEIC), following the prompt advice of the International Health Regulation Emergency Committee. After that, it was classified as a pandemic on the 11th of March, 2020 [50]. In February 2020, Africa joined the rest of the world to battle COVID-19 after the first case was confirmed in Egypt [14].

The first case of COVID-19 was officially recorded in Nigeria on the 27th of February, 2020, in Lagos State. Before confirming the first case, Nigeria was identified as one of the world's countries prone to Corona Virus outbreak due to its cosmopolitan nature [26] and forewarned to develop stringent health measures to combat COVID19. It is commendable that the government established a "Corona Virus preparedness group" through the National Centre for Disease Control (NCDC), which began the point of entry testing and screening for travellers [4]. Due to the COVID-19 pandemic, the subsequent lockdown stopped economic, social, political, and religious activities. All educational institutions and markets across the country were shut down, and people were prohibited from coming out of their houses except for compelling reasons such as cases of ill health and nutritional requirements. The lockdown brought a lot of hardship, such as food and safe drinking water scarcity, environmental pollution, lack of electricity, and lack of access to medical services. The economy was hugely punctured, and social activities were prohibited. It is important to note that hospitals were reluctant in receiving patients with mild and severe health problems, especially illnesses with similar symptoms as COVID-19, such as malaria, during the lockdown. The health workers lamented inadequate and subsequent lack of Personal Protective Equipment (PPE) to effectively fight the COVID-19. Also, the lack of diagnostic centres, drug availability and other medical facilities such as ventilators were severe challenges.

Given that the mode of transmission of COVID-19 includes contact routes and respiratory droplets $[22,44]$, there is a need to develop and enforce stringent health measures to protect the younger ones who have gone back to school and the elderly in the markets, Churches, Mosques, and social centres. This is important because research has shown that asymptomatic and pre-asymptomatic individuals may transmit the infection to others [9]. Although the National Centre for Disease Control (NCDC) has done commendable work in testing and establishing diagnostic laboratories across the country [28], the testing capacity is still deficient, considering the Nigerian population. Therefore, more input is required to effectively eradicate COVID-19 and prevent a third phase of the outbreak. According to the World Health Organization, the total confirmed case of COVID-19 globally as of the 8th of October 2021 was236 132082, including 4822472 death, representing about a $2 \%$ mortality rate. The apex health Organization reported that from the 3rd of January 2020 to the 7th of October 2021, the number of confirmed cases in Nigeria was 206 561 persons, including 2731 deaths (1\% mortality rate).

\section{RESULTS AND DISCUSSION}

\section{People's Perceptions on COVID-19 in Nigeria}

In Nigeria, different people had a different perception of COVID-19; to some, it is just a means through which corrupt Nigerian politicians seek to amass wealth for themselves. On the other hand, some say that the Nigerian government wanted to attract foreign grants. At the same time, there is still some group of people who believe in the existence of the virus. The former reasons were due to poor transparency in public affairs. Nigerian politicians have mostly been charged or accused of misappropriation of public funds or the other. Also, many Nigerians attribute their disbelieve in the existence of the virus to their inability to see any patient who has suffered 
from the virus except for those they see on television. A study by [29] revealed that about a tenth of respondents do not believe that COVID19 exist because they have not seen any victims except for those shown on their TV screens. Another event contributing to the negative perception and neglect of the virus is hunger and starvation. According to [34], the effects most frequently reported by respondents (360) were hunger/low income $(48.8 \%)$ and academic delay (8.8\%).

Furthermore, the distribution of food and relief materials was sabotaged by corrupt politicians who had these foodstuff and relief materials stored in warehouses instead of what they were meant for. On the 26th of October 2020, [59] reported ongoing looting of warehouses for relief materials and food items in Abuja, Nigeria. Reuter said a similar incident on the 9th of November, 2020. According to a [60] network report, the Nigerian government denied hoarding the relief materials and stated they were strategic reserves ahead of a projected second wave. These looting activities got people to the street, neglecting COVID -19 safety protocols.

In a study by [39], it was observed that the general perception of Nigerian youths about the health system and Government handling of the COVID-19 was poor. The research work by [34] revealed that out of a sample of 350 respondents, the following perceptions were observed: $95 \%$ of the respondent would go to the hospital if they noticed the development of any COVID-19 symptoms. In contrast, $58.3 \%$ agreed to call the COVID-19 helplines. Only 26\% knew they could contract COVID-19, while 41 (12\%) perceived it as an exaggerated event. Author [23] found out that out of a survey of 886 participants, only $30.47 \%$ had good knowledge about the virus, $17.8 \%$ had a good attitude, $25.96 \%$ kept good practice. In contrast, over $48 \%$ did not agree that covid-19 originated from animals, 60\% perceived the virus as God's punishment to humanity, and 36\% felt it was an artificial virus.

Furthermore, most of the respondents (63.5\%) expressed fear of contracting the virus, and $56 \%$ admitted to modifying their habits recently in fear of contracting the virus. Author [33] conducted a study on the perception of Nigerians at the early stage of the COVID-19. Their study revealed that in a sample of 1357 respondents, $46.96 \%$ believed that the virus was a biological weapon designed by the Chinese government.
As a means of preventing the virus, [33] reported that $94.25 \%$ of respondents (1357) selected regular hand-washing and social distancing as a way of avoiding infection, while $11.86 \%$ preferred consuming gins, garlic, ginger, herbal mixtures and African foods/soups as preventive measures. [34] reported that the use of face masks (64.5\%) and social distancing (48\%) were the most frequently reported practices for prevention. Only 71 (20.8\%) demonstrated good hand washing practices. They wrote a weak correlation between the likelihood of contracting the virus and methods to prevent it.

\section{Nigerians' Perceptions on COVID-19 Vaccine}

The development of a vaccine was critical to preventing the contraction of COVID-19. Many countries such as the United Kingdom, China, United Arab Emirates, and the United States, among others, have devoted billions of dollars to the production and distribution of COVID-19 vaccines. Still, the consumption or use of these vaccines has faced scepticism, fear and criticism among people, especially in African countries (Nigeria inclusive). The fear and distrust of taking vaccines are not new in Nigeria; for instance, during the monkeypox outbreak of 2017, there was widespread rumours and misinformation that the military was injecting school children with the monkeypox virus. In northern Nigeria in 2003, the political and religious leaders of Kano, Zamfara, and Kaduna states stopped the immunization campaign; they advised parents not to allow their children to be immunized. These leaders argued that the vaccine could be contaminated with anti-fertility agents (estradiol hormone), HIV, and cancerous agents [9]. A report by [27] indicated that the leaders expressed fear that the vaccines had been contaminated with ant-fertility agents by the westerners. The lack of trust in the Nigerian system, ignorance and carefree attitude of people are the key reasons many Nigerians hesitate to take vaccines. Although the vaccine is critical to ending the spread of COVID19 , it has not been generally accepted by the general public as safe and consumable. A survey by [29] on some selected states in Nigeria revealed that out of the numbers of respondents $(1,089)$ consisting of 730 urban dwellers and 359 rural dwellers, a large number of the respondent prefer taking local herbs, visiting a traditional healer, going to chemist or pharmacy at the event of falling ill but will only go to a hospital when the con- 
dition gets worse. As observed by [33], 11.86\% of 1357 respondents preferred consuming gins, garlic, ginger, herbal mixtures and African foods/soups as prevention against COVID-19. The NHW survey revealed that $85 \%$ of respondents had knowledge of the existence of the virus, and over two-thirds were willing to take a vaccine. $56 \%$ of the entire sample had no fear of taking a vaccine, while $44 \%$ indicated fear. Those who stated fear acknowledged that it was due to adverse reactions they had watched and seen on social media, while others were based on religious grounds. The common rumour was that the vaccine was a plan of the devil to insert something harmful into their body. The World Health Organization stated that the number of vaccinated Nigerians was 6852,590 as of the 7th of October, 2021.

\section{Cost of a Pandemic}

Apart from the health challenges currently facing the country, Nigeria is battling a severe economic problem that requires critical therapy, rehabilitation and revitalization. The current exchange rate makes naira disadvantaged in the global economy, facilitating the increasing cost of living in the country. The Corona Virus pandemic and bad economic policies have been the major contributors to the current socio-economic condition of Nigeria. Every epidemic comes with some direct and indirect costs to economies. Author [46] pointed out that the conventional approach uses information on deaths (mortality) and illness that prevents work (morbidity) to estimate the loss of future income due to death and disability. Loss of time, income and direct expenditure on medical care and support services are added to estimate the economic costs associated with the disease. However, this conventional method has some observed lapses as it underestimates the actual cost of these infectious diseases [46]. Author [16] observed that the HIV/AIDS virus affects households, businesses, and governments due to changes in labour supply decisions, labour efficiency, and fall in household incomes. He also pointed to increased business costs and foregone investment in staff training by firms, increased public expenditure on health care and support of disabled and children orphaned by AIDS by the public sector as other effects. Though the impact of HIV/AIDS is long term, there are also measures to reduce the risks of acquiring HIV. Improved medicines such as modern antiretrovi- ral therapies have been found to extend the life expectancies of HIV patients. However, the impact of HIV/AIDS remains highly felt in the economy. Lee and [24] examined the macroeconomic effects of the SARS epidemic in 2003. They found a significant impact on economies through large reductions in consumption of various goods and services, increased business operating costs, and re-evaluation of country risks reflected in increased risk premiums. They noted that irrespective of the small number of cases and death recorded, the global costs were significant and not limited to the directly affected countries.

A study by [52] on the potential impact of COVID19 on GDP and Trade utilizing a standard global computable general equilibrium model indicated significant declines in GDP in both developing and industrial countries. They observed a decrease of approximately $4 \%$ below the benchmark for the world. The worst hit by the lockdown was the outputs of domestic services and traded tourist services.

The [61] opined that the measures to check the spread of the COVID-19 pandemic have led to the temporary shutdown of many businesses, widespread financial market turmoil, an erosion of confidence, and heightened business uncertainty, well as restrictions on travel and mobility [17]. Decline in output, consumer's expenditures and decline in GDP were observed to be the significant impact. The IMF forecasted that the global economy would contract by $-3 \%$ in 2020 . The total loss to world GDP through 2020 and 2021 from the pandemic crisis could be around $\$ 9$ trillion, making it the worst economic downturn since the Great Depression.

In Africa, a study by [17] indicated that the COVID-19-induced lockdown has significantly constrained economic activities and the circular flow of income. He further noted that the perceived reduction in the circular flow of income in the wake of the COVID-19 lockdown has negatively impacted the economic growth in Nigeria. [45] feared that impact of the Corona Virus Disease in Africa is likely to be acute. This is a result of the decline in revenue, employment and output.

Outside economic consequences, pandemics have health consequences. They result in massive deaths, thereby reducing the supply of labour. Some may have life-long consequences. For instance, the Zika Virus has life-long chronic effects on the patient's health. Pandemic also re- 
sults in indirect costs, including depletion of resources for routine healthcare, decreased childhood immunization rates, and reduced healthcare access due to the inability to travel [51]. Author [51] also noted that healthcare workers' ability to provide care is also reduced as they fall ill. These frontline workers are required to take care of family members or children. Even the fear of catching the disease also makes them receptive.

On the socio-political level, pandemic results in social tension and discrimination, especially in nations with weak institutions. For example, author [51] noted that the 2014 Ebola virus resulted in political and social unrest in states as government-imposed quarantine and curfews to mitigate the disease's spread with security forces that the general public perceived as a conspiracy opposing the government. They further stated that the issue caused riots and violence in the countries involved, resulting in healthcare personnel threats, damaging healthcare facilities and supplies. In addition, pandemics sometimes result in clashes between nations. For instance, the US-China tension, the US and some other countries accused China of withholding information about COVID-19. Also, some governments may prefer whom to sell medical provisions and vaccines to and whom not to. These events created tension and disunity among nation-states, thereby weakening international relations.

This perspective seeks to dissect the structure of the Nigerian economy and the effect of the pandemic on Nigeria's economy, having given mild health implications.

\section{The pre-COVID-19 economic structure of Nigeria}

Economic Structure. The Nigerian economy is best described as a mono-product economy. The economy was formally built as an agricultural economy in early Nigerian society. Nigerians were known to be agriculturists from the onset until the discovery of crude oil in Oloibiri, present-day Bayelsa State, Nigeria, in 1956. In the early 90 s, before the discovery of crude oil, Nigeria was self-sufficient in food production. Nigeria ranked top as a net exporter of cash crops such as rubber produced in Delta State (south-south region), Palm oil and kernels produced in Eastern Nigeria, and cocoa and coffee are grown in Western Nigeria. During that period (pre-oil times), the agricultural sector catered for $95 \%$ of the food needs of Nigerians; the industry accounted for $64.1 \%$ of GDP and employed over $70 \%$ of the labour force in Nigeria [37]. Also, the sector accounted for $80 \%$ of export earnings and $50 \%$ of government revenue [32]. Statistics from African Development Bank reveals that in the 1960s, agriculture accounted for $65-70 \%$ of total exports it fell to about $40 \%$ in the 1970 s and down to less than $2 \%$ in the late $1990 \mathrm{~s}$. The oil boom of the 1970s changed the Nigerian economy from one built on agriculture to a net exporter of petroleum products. Crude oil started to account for about $95 \%$ of Nigeria's foreign exchange earnings after the oil boom of the 1970s. A study by [38] revealed that the agricultural sector contributed $57 \%$ of GDP and $64.5 \%$ of export earnings between 1960 and 1969. The sector's contribution declined from 1970 to the late 2000s due to a shift from the industry to crude oil exploration. The industry had only contributed an average of $23.5 \%$ of GDP and $5.1 \%$ of export earnings in 5 years. In 2016, the agricultural sector accounted for $24.4 \%$ of GDP but just $4.8 \%$ of export earnings, unlike Brazil. The agricultural sector alone contributed to $46.3 \%$ of export earnings for the same period [38]. According to Budget Office, non-oil revenue, including revenue from the agricultural sector, constitutes $38 \%$ of government revenue and 23\% of export earnings in 2019. This indicates that many agricultural products are consumed locally, relying heavily on crude oil for foreign exchange earnings. Irrespective of local consumption to export, Nigeria remains an importer of almost all food commodities.

Agriculture is regarded as the mainstay in many African countries. The desire of nations to achieve food security and adequacy makes the agricultural sector paramount for national development. The Food and Agricultural Organisation (FAO) recommends that $25 \%$ of the government capital budget be allocated to agricultural development. This is not the case in Nigeria, especially after discovering crude oil. Since the discovery of crude oil, the attention given to the agricultural sector in Nigeria has continued to decline; for instance, expenditure on agriculture, as a percentage of overall spending, fluctuated from $4.57 \%$ between1986-1993 to an average of $4.51 \%$ per annum between 1994-1998 and to $3.53 \%$ between 1999-2005. Author [31] commented that the Nigerian economy has also failed to reach the 10 per cent agriculture budget standard of the Maputo declaration, which has led to negative 
implications for food security. The continued reduction in agricultural expenditure over the years relative to the overall spending of Nigeria has led to inadequate funds for the sector [36]. This has, among other things, reduced food security and availability in Nigeria. [12] estimated that the number of undernourished Nigerians increased to 25.6 million people between 2016 and 2018 from 9.1 million between 2004 and 2006, indicating a $281.32 \%$ increase. Despite various programmes and policies adopted by the Nigerian government to promote agriculture, the sector still performs. The poor performance from the agricultural industry can be related to the insufficient budgetary allocations, policy implementation and policy continuity in the industry.

Nigeria consumes over $60 \%$ of its agricultural produce locally; yet, Nigeria remains a major importer of foods and agricultural produce despite its vast arable land, working population and potential to produce food and agricultural products. Statistics from 2016 shows that the top five agricultural export includes cocoa (\$698 million), oilseed and oleaginous fruits (\$216 million), fruits and nuts ( $\$ 156$ million), milk, cream and milk products ( $\$ 68$ million) and spices ( $\$ 48$ million) while the top five imports are fish $(\$ 1,461$, wheat $(\$ 1,070)$, sugar, molasses and honey (\$373 million), milk, cream and milk products (\$295) and fixed vegetables, fat and oil (\$250 million) [38]. This shows a trade deficit of $\$ 2,263$ million. The import of just fish alone covers the total export of the top five products. Aside from being an importer of food and agricultural produce, Nigeria is still a net importer of general merchandise such as machinery, computers, cars, pharmaceuticals, glass and glassware, Plastics Cereals etc. Despite being the largest oil producer in Africa, the 8th largest reserve in the Organization of the Petroleum Exporting Countries (OPEC) and the world's 4th largest exporter of liquefied natural gas, many petroleum products used in Nigeria are imported. The manufacturing sector of the Nigerian economy has not been up to the task of producing quality commodities needed by Nigerians; most Nigerians, especially elites, demand foreign-made goods due to the sub-standard nature of most locally made products. According to statistica.com, the manufacturing sector in Nigeria accounted for $13 \%$ of GDP in 2020 . Value addition in the manufacturing sectors has witnessed a steady decline from 1995 . It only started to pick since 2010. The recession of 2016 caused a de- cline through 2017. Manufacturing value addition caught a boost in 2018 and 2019.

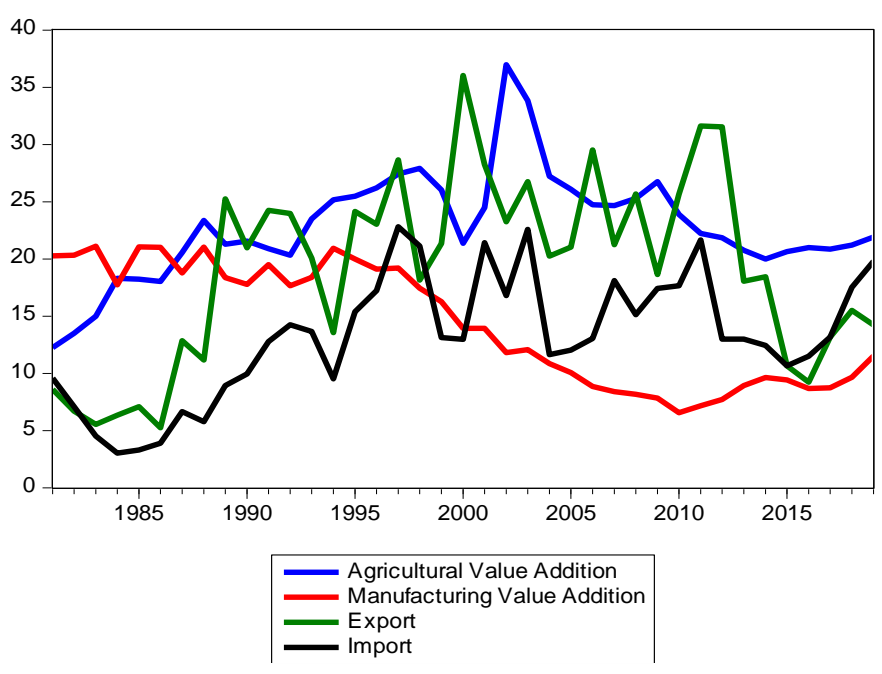

Figure 1 - Output, Import and Export

Among the things observed from the figure is the inverse direction followed by the agricultural and manufacturing value addition trends. This indicates a negative correlation or link between the sectors. Also, manufacturing value addition has continued to fall, as indicated by the downward trend. The decreasing value addition in the manufacturing industry signals high production costs and a weak productive base in the economy. However, there is an observed improvement in 2018 and 2018. The manufacturing trend relates to the decreasing contribution of the manufacturing sector to total export. It further implies that most manufactured goods in Nigeria are not exported but consumed locally. This may be due to the low export quality or high absorption rate. The Absorption principle states that total domestic demand equals total domestic production plus all imports. Export can only be possible if the domestic output is large enough to satisfy domestic needs. Thus, export can be expressed as $\mathrm{E}=\mathrm{Q}-\mathrm{A}$, where $\mathrm{E}$ is export; $\mathrm{Q}$, - national production and $\mathrm{A}-$ absorption. Absorption is the part of national output plus imports that are consumed locally. When the domestic production is low given a high absorption rate, the export will be small and vice versa. Export can only be improved if output grows faster than the population growth rate. Also, crude oil product takes a larger share of export revenue in Nigeria which reduces attention on the non-oil sector. On the side of import, the import trend indicates that importance has increased over time to surpass domestic production. 
On the other hand, agricultural value addition indicated continued improvement with a peak of $37 \%$ in 2002 . However, it declined subsequently. It took until 2015 for the trend to show any form of progress. Export and import (\% of GDP) have followed a similar pattern indicating they are both income functions. Export has been greater than import in most cases except for 1982, 1998, 2016 and 2018 and 2019.

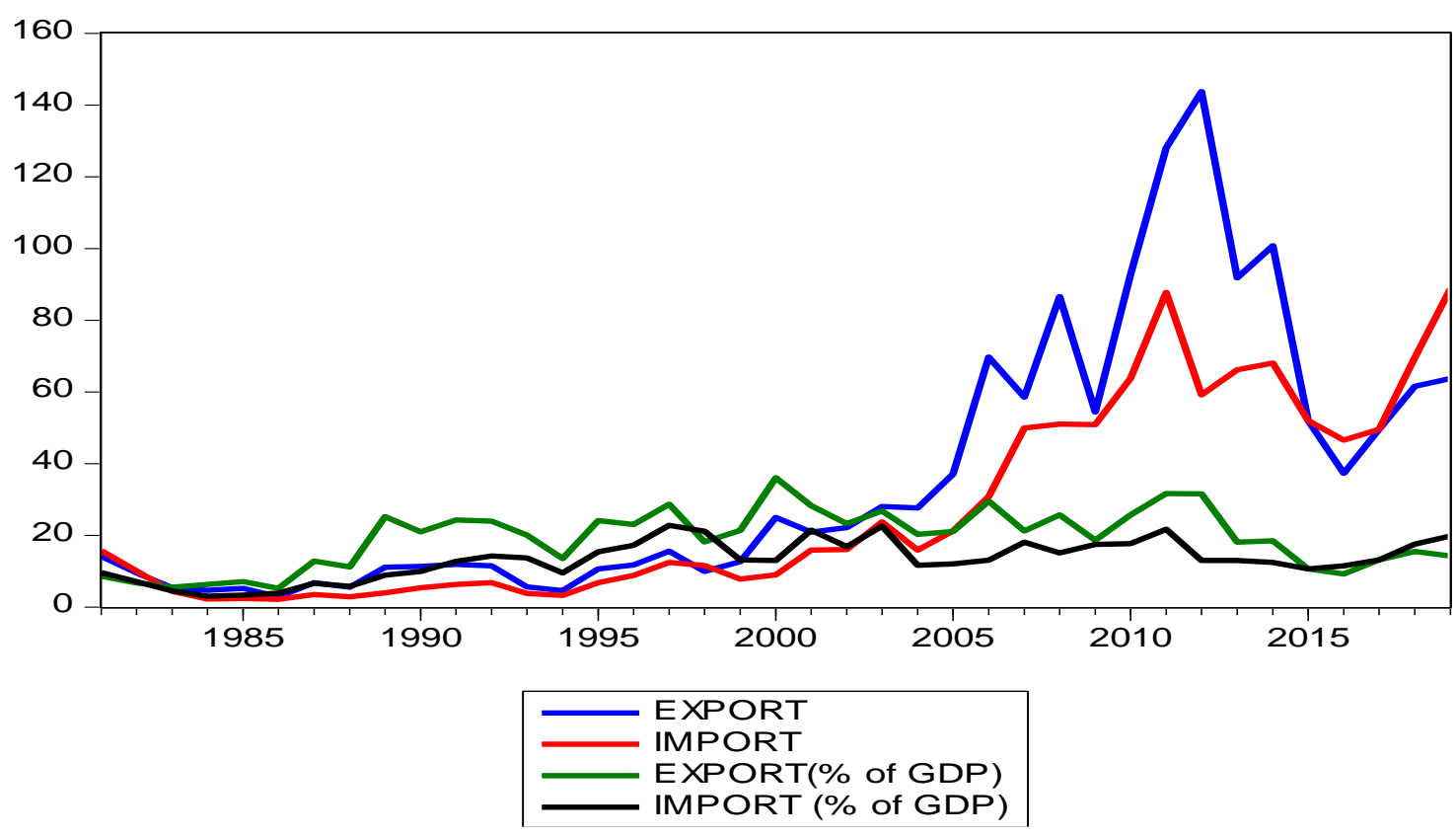

Figure 2 - Export-Import (\% of GDP) Trends

The trend line on imports indicates that between 1960 and 1973, a more significant fraction of GDP was spent on importation to the income on export. The oil shock of 1973, which caused a spike in oil price from $\$ 4$ to nearly $\$ 12$ globally, led to imports and exports rising sharply to over $19 \%$ and $29 \%$ of GDP respectively in 1980 . In that same year (1980), the global oil market faced an oil glut, leading to a fall in oil prices from over $\$ 35$ in 1980 to below $\$ 10$ in 1986 . This was reflected in the export-import figures as shown in the graphs above. The export sector experienced a sharp rise from 1988 to 1990 while imports grew less. Both sectors have experienced swing-swag movement with peaks (export) in 1980, 1989, 1997, 2000, 2003, 2006, 2008 and 2012 as percentages of GDP. Export had peaked in 1974, 1980, 2000 and 2012. On the other hand, imports had peaked at 1981, 2003, 2006, 2007, 2008, 2010, 2011 and 2019. As a percentage of GDP, it had peaked at 1960, 1967, 1976 (highest peak), 2011 and 2019. The declining import percentage of GDP does not imply that Nigeria imports less than before. It only indicated that the GDP basket is more significant than before. Taking a ten-year average, export as a percentage of GDP from 1960 to 1969 was $9.8 \%$ by
1979 , it rose to $17.7 \%$, it fell to $11.8 \%$ in 1989 , and it then rose to $21.8 \%$ in 1999 and $25 \%$ in 2009 before falling to $18.8 \%$ in 2019 . For import, between the same periods as export, importance on the average was 15.5, 17.8, 7.2, 15.0, 16.1 and $15.0 \%$ respectively. These statistics show how closely import and export as percentages of GDP have been. In fact, after the recession of 2016, the volume of imports has significantly risen. This made Nigeria highly vulnerable to a fall in output due to the global lockdown.

Take a timeframe closer to the Coronal virus era, for instance, 2015 through 2019; import outweighed export. This situation has consequences, among which are: exchange rate depreciation, inflation, fall in foreign exchange reserve and balance of payment deficit etc. Most firms in Nigeria depend heavily on imported input, making the demand for imports inelastic to price. Excess substances make a domestic currency less competitive in the foreign exchange market, but they also can choke local industries. Depreciation of the Naira implies costlier imports, reflecting on production cost and price. To reduce the import effect on exchange rates, the CBN will attempt to use its foreign exchange reserve by flooding the US dollars into the market to buy naira, thereby 
reducing its budget. The question is, "how long can they do that?" Such action can only sustain the depressed naira for a while, after which. It will continue to decline in value if measures are not implemented to increase export, foreign direct and portfolio investment and any other activity that implies exchanging the dollar for naira. Import-export imbalances in Nigeria have had a significant impact on the balance of payment position of the country. According to data obtained from the Central Bank of Nigeria, the current account percentage of GDP fell from $32.84 \%$ in 2005 to $8.33 \%$ in 2009 . It continued downwards to negative $3.19 \%$ and $3.58 \%$ in 2015 and 2019 . According to the data, the current account percentage of GDP has declined since 2005, reflecting excess imports over exports. Overall, the balance of payment as a percentage of GDP maintained a downward trend in 2005 through to
2009 before indicating a slight improvement from the previous of -6.31 to -2.73 in 2010 and 0.09 in 2011. It fell back into negatives in 2012, 2016 and 2019.

Foreign Investments in Nigeria. Foreign investment includes both portfolio and direct investment. It is believed that a nation's growth and sustainability depend on its ability to attract foreign investments. There are several advantages to doing so; technological transfers, capital inflow, improved export, spillover to domestic firms, exchange rate improvement, employment, increased tax revenue to the government and increased consumer choice and satisfaction are some of them. But unfortunately, data shows that Nigerians has not been able to attract much foreign investment.

\section{FDI}

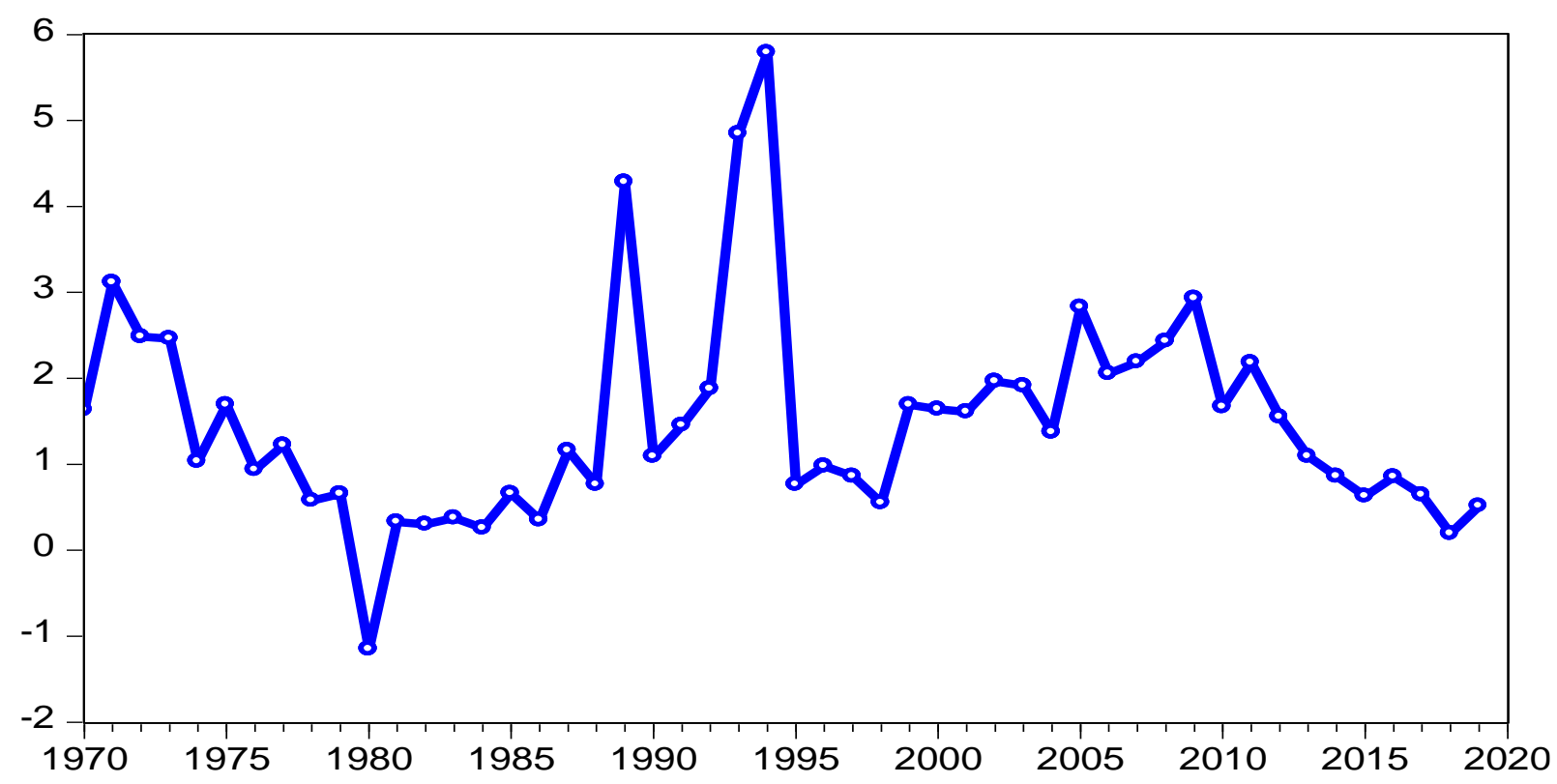

Figure 3 - Foreign Direct investment (1970-2019)

The diagram above represents the net inflow of foreign direct investment as a percentage of GDP in Nigeria. 1980 witnessed the lowest net inflow of FDI into Nigeria with a value of $-1.15 \%$. The period with the highest value was 1994 with $5.79 \%$. It dropped to $0.76 \%$ in the following year. On average, net foreign direct investment (\% of GDP) only grew by $1.79 \%$ from 1996 to 2009 . FDI has continued to show no significant improvement as indicated by the downwardsloping curve from 2011 with a slight improvement in 2019, averaging at $1.02 \%$ from 2010 to 2019.
Risks of Over-Dependence on a Single Commodity. Before discovering crude oil in Nigeria, no one imagined that oil could take centre stage of economic importance in Nigeria. When crude oil was first found in Nigeria in the fifties, the prognosis was that Nigeria would never become more than a dot on the world oil map [35]. Nigeria is the 11th highest producer and 8th highest exporter of crude oil and 13th highest exporter of natural gas globally. Nigerian crude oil is undeniably one of the most demanded crude oil worldwide, accounting for about $90 \%$ to $98 \%$ of foreign exchange earnings in Nigeria. This high de- 
gree of dependency on oil has brought a lot of associated risks, namely:

The risk that our products could fall due to domestic factors such as civil unrest and sabotage, the risk that the demand for our oil could fall mainly due to external factors like the COVID-19. The chance that the price might decrease due to external forces like OPEC decisions, oil glut etc. Threats of a revenue shortfall due to the interplay of internal and external forces such as low production, low demand, fall in oil price, etc., the country could run out of reserves or risk complete depletion [35]. These associated risks make the Nigerian economy highly vulnerable to external and internal shocks.

Impact on External Reserve. Authors [19] defined foreign exchange reserve as "consisting of official public sector foreign assets that are readily available to, and controlled by the monetary authorities, for direct financing of payment imbalances, and directly regulating the magnitude of such imbalances, through intervention in the exchange marketing to affect the currency exchange rate and/or for other purposes". The external reserve serves as a store of a nation's excess income and regulates the exchange rate. Factors that affect foreign reserves include import, export, external debt and exchange rates. Since inflation makes local commodities expensive and reflects on the exchange rate, inflation can also determine external reserve position. Author [8] stated that a high inflation rate could affect reserves because the funds needed are used to stabilize the value of the foreign exchange rate.

The exchange rate position strongly determines external reserves. Since the foreign accounts are expressed in dollar amounts, naira depreciation will invariably result in a fall in foreign reserves. In addition, the continued use of foreign exchange reserves to correct foreign exchange disequilibrium occasioned by the weak internal economy sectors and less competitive demand for naira has further plunged the foreign reserves. Outside of stabilizing exchange rates, external resources serve as a buffer to external shocks [40]. Thus, depletion of external reserves implies less resistance to external shocks.

In a general sense, the Nigerian economy has been an import-dependent economy with a weak export sector, depreciating exchange rates, depleting external reserves and persistent balance of payment deficit. Moreover, an increasing population estimated to be 201 million, an annual population growth rate of $2.6 \%$ in 2019 , an underperforming economic base, and a monoproduct economy's associated risk render it highly vulnerable to shocks. Due to the weak internal structure of the Nigerian economy, the nation has experienced three wonders between 2009 and 2021. First was the 2009 economic crisis which was the aftermath of the 2007/8 financial crisis, the second was the 2016 economic recession caused by the global oil glut, and the third was the global recession of 2020 caused by the COVD19. A more resilient economic structure would have saved the nation from the first two and reduced the third effect.

\section{Social Structure}

The socio-economic setting in Nigeria has been filled with chaos, political tension and unrest since independence. This has been reflected in the poor levels of development, especially in the northern and eastern parts of Nigeria. Relative peace and stability are the most important factors that investors consider before investing, especially when such an investment is made away from home. Figure three shows that Nigeria has not attracted enough foreign direct investment. The government of Nigeria has paid little attention to relevant social sectors of the economy, such as the health and educational sectors. Before the Corona Virus disease of 2019, which saw an increase in government spending on health, there had been little investment by the government in the sector. The educational industry also faced poor funding and infrastructural deterioration, especially in public schools.

Health Sector. The health sector is one of the most critical sectors in any economy; this supports the saying that "a healthy nation is a productive nation". Given the observed impact of health and well-being on productivity and national growth, nations of the world must continually allocate vast amounts of money to improve their health sector. A study by [13] revealed that public spending and health outcome are closely related. The World Health Organization recommended at least $15 \%$ of the total budget to the health sector. However, this is not the case in Nigeria, where investments in the health sector have been less than $10 \%$ of the total budget.

The health sector in Nigeria has faced neglect, poor funding, insufficient bed per head and decaying infrastructures. Government expenditures 
to all industries in Nigeria have continued to increase yearly (health sector inclusive). However, as a percentage of total spending, allocation to the health sector has not improved. Statistics show that between 1986 and 1990, health expenditure as a percentage of GDP averaged $0.32 \%$ and only improved to $0.33 \%$ between 1995 and 1999. Author [42] revealed that Nigeria's spending in the health sector is lower than $16 \%$ of GDP. Between 2000 and 2007, government expenditure on health averaged about $2.1 \%$ to $5.8 \%$ [25]. Apart from inadequate budgetary allocation to the health sector, the few health infrastructures available are unbalanced between urban and rural areas. Between 2010 and 2017, government expenditure allocation to the health sector in the percentage of total expenditures was $3.58,5.58,5.95,5.66,5.78,4.13$, to $5.17 \%$, respectively are lower than the WHO benchmark [41].

Apart from the call for increased budgetary allocation to the health sector, management and fiscal implementation play a vital role in ensuring that the desired outcomes are reached. World Bank in 1998 identified bad budget management as one of the main reasons for inefficient public spending in many developing countries. On the other hand, author [7] attributed public spending efficacies to good governance.

The Economic and Financial Crime Commission in 2005 stated that corruption has stunted growth in all sectors of the Nigerian economy. Author [5] concludes that in Nigeria, corruptions stifle economic growth; reduce economic efficiency and development despite the enormous resources in the country. In addition, it devalues the quality of human life, robs schools, agricultural sectors, hospitals and welfare services of funds. In 2004, Transparency International (TI) released the Corruption Perceptions Index, ranking Nigeria the third most corrupt country globally. In 2020, [53] ranked Nigeria 149 of 180 with a 25 of 100 . Nigeria's score had only reduced by two since 2012. The high level of corruption in Nigeria makes room for doubt on the effective use of the resources available to the government. Most times projects worth millions of dollars are left unattended, and politicians loot funds. In the least bad scenarios, the projects are done using sub-standard equipment or left unfinished.

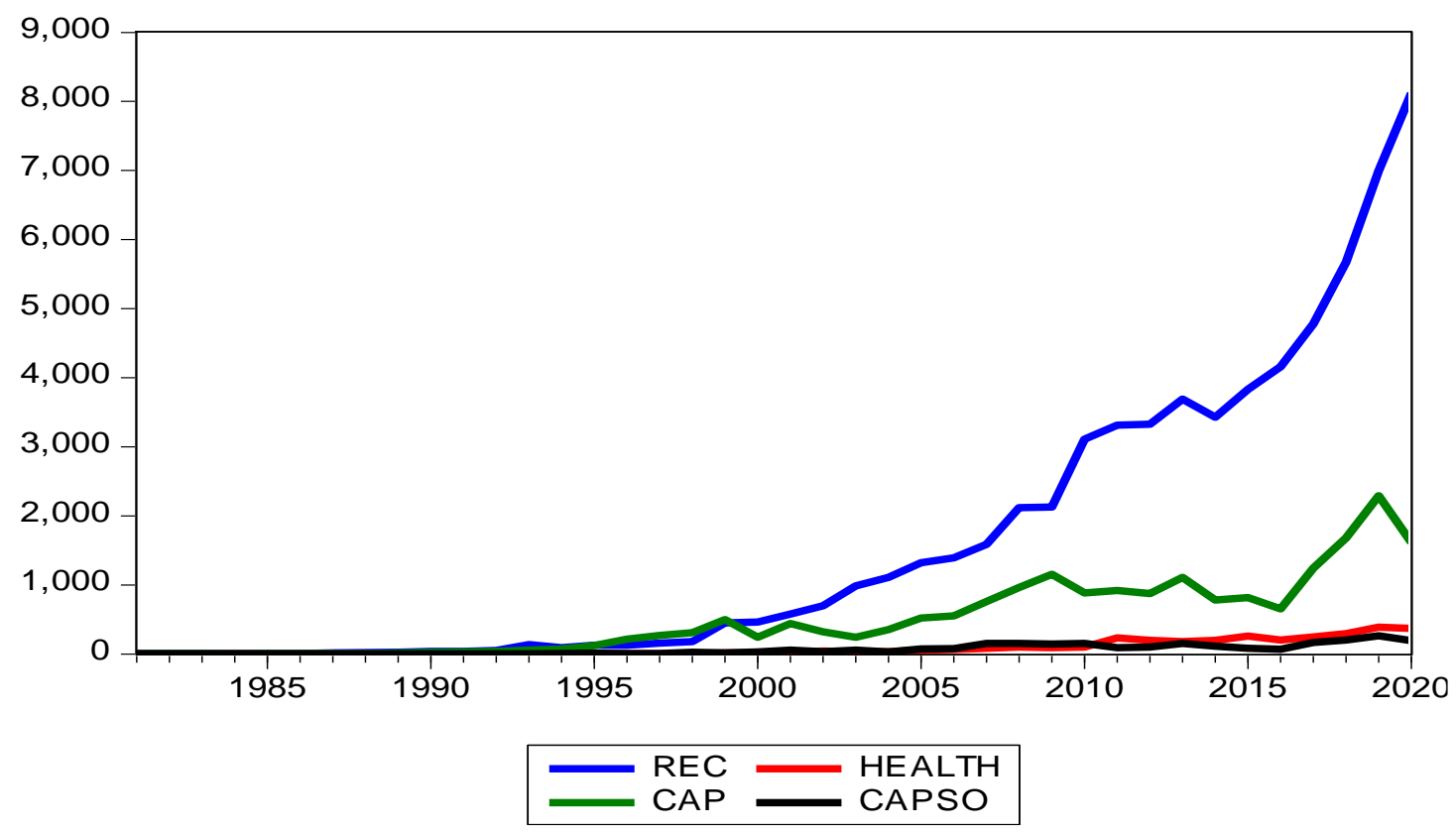

Figure 4 - Government Expenditures on Health

The red line represents recurrent government expenditures to the health sector, while the black line represents government capital expenditures on social services, including the health sector. The blue and green lines represent government total recurrent and total capital expenditures, respectively. These trends reveal an obvious gap between the total and the allocation to the health sector. This insufficient funding has created a void on health performance in the country.

In 1999, Nigeria was ranked 74th out of 115 countries, based on the performance of some selected health indicators. Among 191 member states, the WHO in the year 2000 ranked Nigeria 
187th on overall health performance. A report by the [63] stated that Nigeria was rated 187th out of 191 countries in terms of health care delivery by the World Health Organization in 2019. The report also noted that Nigeria was placed Nigeria as the third-highest maternal and infant mortality rate globally, with about $70 \%$ of the country's population still spending out-of-pocket for health services.

The health sector's poor state, especially in developing countries, possesses huge challenges and the prevalence of large-scale health problems. The Infant Mortality rate has remained high, coupled with low life expectancy and poor sanitation due to scarce health resources. According to the WDI report, the Nigerian population was 206139587 million in 2020. Author [54] reported that between 2006 and 2011, the Nigerian population growth rate averaged $2.55 \%$. The population growth rate was $2.6 \%$ from 2015 to 2019 and declined to $2.5 \%$ in 2020 . The fertility rate was as high as 6.5 per woman in 1990 but have declined in subsequent years. It was 5.8 in 2011 and 2012, 5.6 in 2015 and 5.3 in 2019 . The mortality rate under five per 1,000 has shown slight improvement over time. The rate was 209.5 in 1990 , declined to 133.6 in 2011, $131.7,129.9,128.5,126.8,125,122.8,120$, and 117.2 from 2012 to 2019 [54]. According to [47], bed per head for every 1000 peaked at 6.37 in 1988. By 1999, it had fallen to 1.67 , and by 2004 , it was 0.5. Life expectancy in Nigeria has increased slowly to reach 53 years in 1991. The life expectancy was 48.2 years for females and 46.8 years for males in 1999. The disability-adjusted life expectancy for Nigeria was 38.3 years for females and 38.1 years for males in 1999. The life expectancy rate improved from 48.8 years in 2006 to 50.4 years in 2011. In 2015, it was 53.1 and 54.7 years in 2019.

On overall human capital index, Nigeria's HDI improved only slightly from the last two decades; $0.465,0.482,0.526,0.526,0.531,0.534$ and 0.539 in 2005, 2010, 2015, 2016, 2017, 2018 and 2019 respectively. Between 2005 and 2019, Nigeria's HDI value increased from 0.465 to 0.539 , an increase of $15.9 \%$. Between 1990 and 2019, Nigeria's life expectancy at birth increased by 8.8 years [42]. This has placed Nigeria low ranked among other countries and territories. In 2012, for instance, Nigeria ranked 153rd position among 187 countries on the HDI ranking 2012 with an HDI value of 0.47 . 0. In 2019, Nigeria ranked 161 of 189 countries and territories with an HDI of 0.539 .
In a nutshell, there have been insufficient investments in human capital, particularly in the health and educational sectors. The fragile state of the health sector left Nigeria highly vulnerable during the early periods of the COVID-19. The nation struggled with managing the increasing number of infected persons and available health infrastructures. There were problems like limited beds per head, isolation and testing centres, life supports etc. which were highly important at those periods. Our developed counterparts returned to their research and development institutions to provide insulators, life-support machines, and personal protective equipment. Still, such provisions could not be gotten in Nigeria due to its fragile and unproductive level of research and development. Among the several problems faced by the health sector, the most identified are the lack of fund and human resource management, rural-urban distribution imbalance, infrastructural inadequacies and poor maintenance.

Before the Corona Virus disease of 2019, Nigeria had been experiencing high levels of insecurity; the Boko Haram in the north; Fulani Herdsmen spreading from the north to the south-east, south-south and south-west; the militant in the south-south region and clashes between government forces and the Indigenous People of Biafra (IPOB) in the east. These have resulted in a high level of instability in the country. Livelihood and economic activities have been made difficult in the country and especially in the affected areas; there have been food shortages due to the destruction of farmlands and the killing of farmers. There have been reduced economic activities due to fear of being killed, the limited infrastructures have been destroyed in the process of crisis, and these have resulted in a low rate of investment, employment, a spike in food prices and loss of investor confidence in these regions and a cumulative impacts on the overall economy.

\section{The Economic Impact of COVID-19}

The covid-19, like every other pandemic and health crisis, was unplanned for; it came as a shock to everyone and lingered because it was new and needed a lot of time for scientists to study its generic features, which will enable them to develop vaccines. The laps of time between the initial development of the virus and developing a vaccine saw economies of the world crying for aid, especially in less developed countries. To 
date, economies of the world are still recovering from the impact of the pandemic. An effective preventive method against contracting the virus was social distancing; this implied distancing oneself at least two meters from the next person. The implementation of social distancing rules led to the closing of workplaces, factories and manufacturing sites, leading to shortages in output, rising unemployment, low incomes and substandard living. Only health workers and other workers regarded as essential workers were allowed to work in full compliance with COVID-19 protocols, while extensive cooperation required their workers to work from their homes. Another preventive measure the national government took was restricting travel to and from other countries. It was observed that most of the confirmed cases of COVID-19 were imported from other countries. The economic implications of restricting travels included but were not limited to declining world output levels, low business activities on domestic and external sectors such as exports, imports, technological transfers and any form of investment, thus increasing the overall negative impact of the pandemic on output, income, employment and economic growth. The most affected by the global lockdown are importdependent nations such as Nigeria. Nigerian industries depend on other countries (import) for most of their inputs in the production processes, and with the closing down of international borders, these firms could no longer operate or operate below capacity. Also, most of the goods bought and consumed by Nigerians are imported.

The combined effect was a shortage in goods and services available to Nigerians during that period. These led to skyrocketing inflation and un- employment rates. The one Economist classifies as stagflation and exchange rate depreciation. The economic structure of Nigeria is best described as a mono-product economy; this is because crude oil is the major contributor to national income. The natural oil market is volatile and depends on demand and supply interactions. The volatility of crude oil prices makes Nigeria vulnerable to external shocks from the international market. For instance, the 2016 recession was attributed to the oil glut in the global market, which led to a sharp decline in oil prices from about \$105 in 2013 to about \$41 in 2016. There have been various failed attempts by the government of Nigeria to achieve economic diversification. Crude oil exports contribute a more significant chunk of total revenue to the government yearly. At the same time, sectors like agriculture and manufacturing are faced with the underutilization of resources.

A study by [21] revealed that crude oil price fluctuation has a positive impact on the economic growth of Nigeria. Author [62] observed that crude oil prices are the primary determining factor of the exchange rate, cost of borrowing and directly influences inflationary and deflationary tendencies in Nigeria. This study implied that crude oil is Nigeria's most significant export commodity and determines other macroeconomic variables' direction. Author [1] concluded that oil price is a substantial source of shocks to macroeconomic variables in Nigeria.

The graphical representation below represents the trends of total revenue, non-oil revenue and oil revenue in Nigeria between 1981 and 2019.

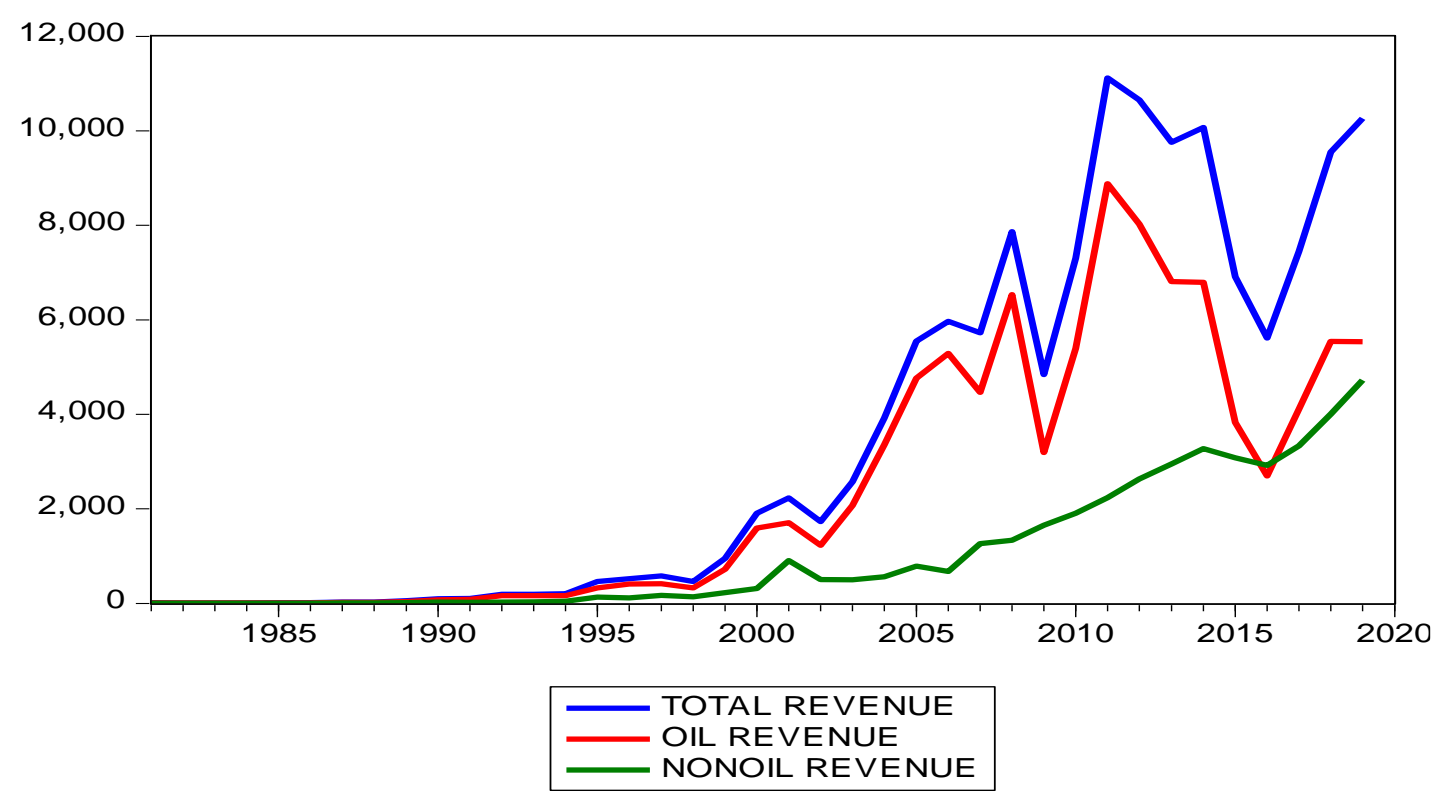

Figure 5 - Revenue Trends 
Figure 5 shows a strong link between total revenue and oil revenue in Nigeria. According to the Budget Office, crude oil constitutes about $62 \%$ of government revenue and $77 \%$ of export earnings in 2019. As indicated by the above representation, there is a significant disparity or gap between total and non-oil revenue, implying the insignificant nature of the non-oil sector to the Nigerian economy.

The non-oil sector experienced significant improvement from 2008 and continued until 2015. The 2016 economic recession also affected productivity in all oil sectors. However, the oil sector was most affected. The global oil glut caused the recession. As shown above, total revenue has followed a similar pattern with oil revenue, indicating a significant relationship between both.

Among other political administrations in Nigeria, the 2015-2023 administration has been more active in achieving economic diversification; the steeper non-oil revenue curve shows this from late 2016 to 2019.
However, much is needed to reduce the Nigerian economy's vulnerability to crude oil fluctuation. The global lockdown substantially affected the demand for crude oil, especially in the early quarters of 2020; the demand for crude oil fell drastically during these periods. This was due to the closedown of factories, restricted travels and close down of businesses that needed crude oil or crude oil-related products for their operations. These resulted in a fall in crude oil prices as supply outweighs demand for crude oil. For instance, during the early stage of the COVID-19 pandemic, WTI crude oil price fell as much as to negative territory ( $-\$ 37$ per barrel) on the 20th of April 2020. This was because demanders of crude refused to redeem their contracts, and the storage for crude was almost filled up. At that point, crude oil companies paid buyers to accumulate the excess crude oil from their reserves to avoid a collapse of their storage facilities. OPEC Basket monthly data revealed that crude oil prices fell from $\$ 63.65$ in January 2020 to $\$ 17.66$ in April 2020. It took till the beginning of the third quarter to see a significant rise in the price of crude oil. From July to December 2020, the average cost of crude oil was $\$ 43.66$.

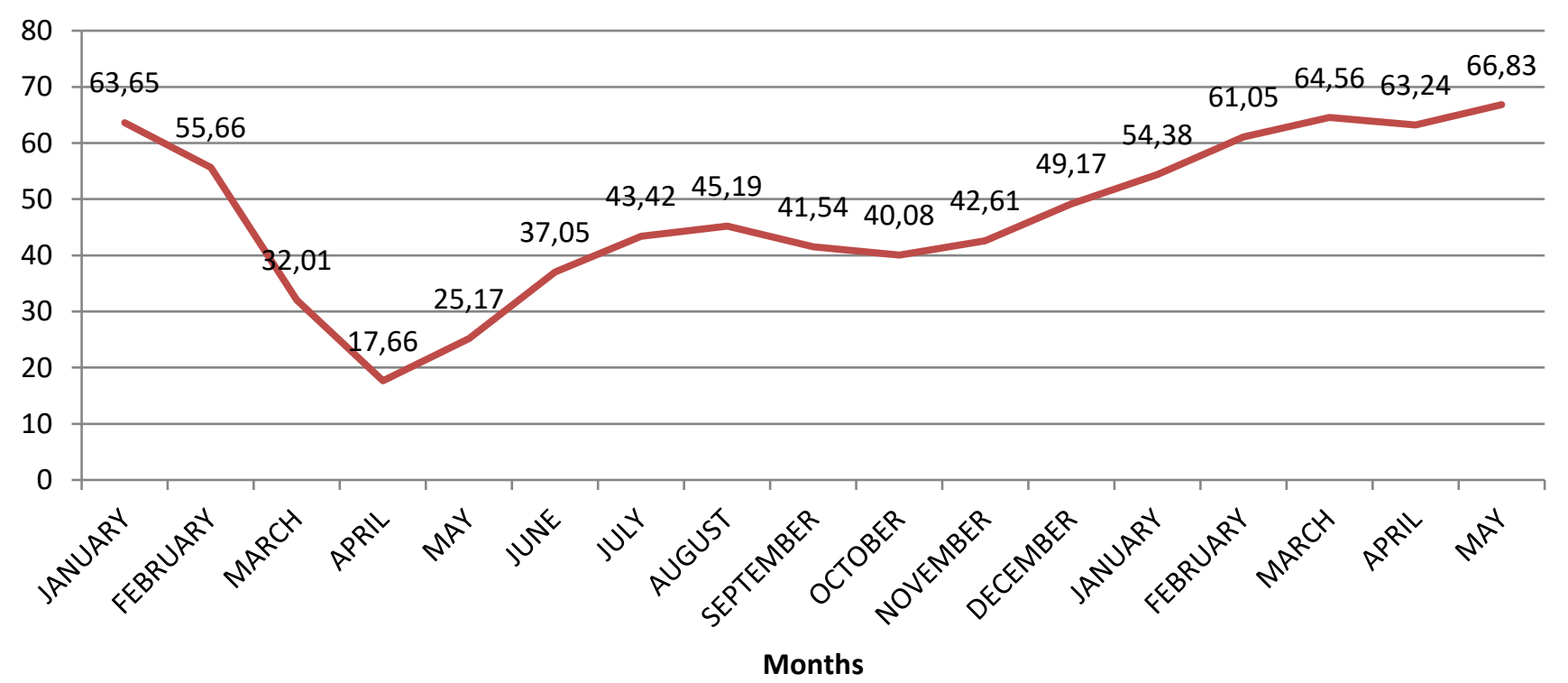

Figure 6 - Monthly Prices of Crude oil (January, 2020-May, 2021)

It took until January 2021 for crude oil prices to gain significant momentum; this was because as at that period, countries were starting to ease restrictive policies which allowed production and other business activities to operate.

Among other things affected by the drastic fall in crude oil prices of 2020 is the change in budgetary allocation and fiscal plans. For instance, the
2020 budget passed by the Nigerian legislature in December 2019 was 10.594 trillion (expenditure) and $\$ 8.419$ trillion (revenue) with an oil price benchmark of $\$ 57$ per barrel, oil production of 2.18 million barrels per day and exchange rate of $\$ 305 / \$$. The budget was reviewed twice due to declining oil prices associated with the covid-19 pandemic. First, the budget was revised down- 
wards to 10.27 Trillion (expenditure), \#5.08trillion (revenue) benchmark of $\$ 23$ per barrel, oil production of 1.70 million barrels per day and exchange rate of $\$ 360 / \$$ thereby slashing revenue projection by about $40 \%$. The approved budget was revised to $\$ 10.811$ trillion (expenditures) and \$5.835 trillion, indicating about $31 \%$ drop from the initial revenue. The benchmark was \$28 per barrel, 1.8 million barrels per day and a 360/\$ exchange rate (Office of Budget and Planning, 2020).

\section{Impact of COVID-19 on Macro-Economic Variables}

Inflation. Among other macroeconomic variables affected by the COVID-19 pandemic, inflation and unemployment were the foremost. The price of virtually everything has gone up; the cost of living is now very problematic. With the associated rising unemployment rate and declining per capita income, most Nigerians have been dragged into poverty and untold hardship. Author [6] reported on the 15th of June, 2021, that Nigeria's surging inflation rate could be respon- sible for pushing 7 million Nigerians into poverty and criminal activities. Statistical data revealed that inflation rates increased from late 2019 and remained high in the third quarter of 2021.The rate was $12.56 \%$ in June 2020, 12.82, 13.22, $13.71,14.89,15.75,16.47,17.33,18.17,18.12$ and $17.93 \%$ from July 2020 till May, 2021 respective. As of May 2021, core inflation hit $13.15 \%$.

Statistics revealed that the inflation rate rose by 16.5\% between January 2020 and January 2021. CBN data put the inflation rate at 18.12, 17.93, and $17.75 \%$ in April, May and June 2021, respectively, on year-on-year changes. A report from [11] stated that the inflation rate dropped to $17.01 \%$ in August from 17.38\% in July 2021. It represents a $0.37 \%$ decline in inflation from the figure obtained in July. However, on a month-tomonth basis, headline inflation increased by $1.02 \%$ in August 2021. The report noted that food inflation was as high as $21.03 \%$ in July but fell to $20.3 \%$ in August 2021, while core inflation fell from 13.73 in July to $13.41 \%$ in August 2021 [11].

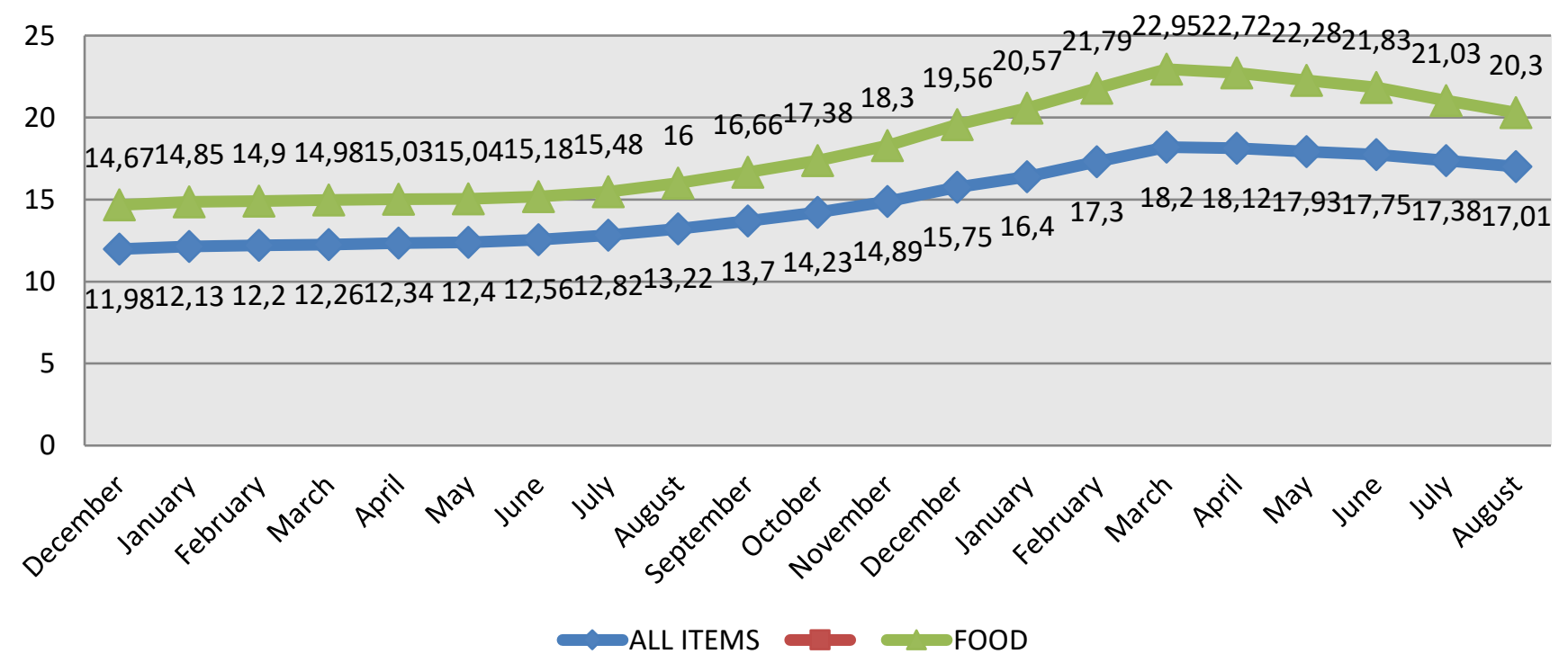

Figure 7- Inflation

As shown by the above diagram, the inflation rate in Nigeria was just 11.98\% in December 2019, with food inflation at $14.67 \%$. However, these went as high as 18.12 (all items) in April and 22.95\% (food) in March 2021. Despite the observed downward trends since May 2021, inflation rates are still very high compared to the preCOVID-19 era.
Unemployment. When inflation and unemployment move in the same direction, it speaks doom for an economy experiencing such. Such a situation is regarded as stagflation. The Nigerian economy has been experiencing stagflation for a long time now, but the COVID-19 has worsened matters. The global pandemic shut down industries and nations' entire economies, making it 
impossible to engage in economic activities except for essential works and big firms that could afford the work-from-home policy. Other smaller firms that could not operate had no choice but to lay off workers. The informal sector, which constitutes a more significant percentage of the $\mathrm{Ni}$ gerian economy and employs a larger share of her labour force, was the most affected. Employees of this sector had dual issues to worry about: job loss and the risk of contracting the virus.

A report by Bloomberg.com revealed that the unemployment rate in Nigeria rose to $33.3 \%$ in the last quarter of 2020 . This figure is more significant than $27.1 \%$ in the second quarter of 2020 . Data from that period revealed that the total number of people in employment during Q4 of 2020 was 46,488,079. Thirty million five hundred seventy-two thousand four hundred forty of the whole figures (representing 66\%) were fulltime employed (i.e., worked $40+$ hours per week). In comparison, 15,915,639 representing (44\%) were under-employed (i.e., working between 20-29 hours per week). This figure is $20.6 \%$ less than the number of people in employment in Q2, 2020. The rural dweller was the most affected by the unemployment rate. The unemployment rate among rural dwellers rose from $28.2 \%$ in Q2, 2020 to $34.5 \%$ in Q4, 2020, while urban dwellers rose from 26.4 in Q2 2020 to $31.3 \%$ in Q4, 2020. In addition, youth unemployment for that. Given the high levels of unemployment and inflation coexisting with lowincome groups in the country, plus the growing population and dependency ratio, one can only wonder the extent of hardship Nigerian's face. This twin scenario of rising inflation and unemployment makes it more difficult to kick start the economy.

Economic Growth. The Nigerian economy fell into recession in 2020 after contracting by $1.79 \%$ in 2020 (y-o-y) from 2.2\% in 2019 [54]. Before the COVID-19, the World Bank forecasted that the Nigerian economy would grow by $2.1 \%$ in 2020. Data from the National Bureau of Statistics revealed that quarterly, the GDP growth rate at the introductory price was $1.87 \%$ in Q1, 2020, from $2.55 \%$ in Q4, 2019. It contracted further by $-6.1 \%$ in Q2, 2020, -3.62\% in Q3 and a marginal growth rate of $0.11 \%$ in $Q 4,2020$. On year on year basis, the Nigerian economy contracted by $1.79 \%$ in 2020 . It grew by $0.51 \%$ in Q1, 2021. The NBS reported that the growth rate of Q2, 2021 was $12.80 \%$ higher compared to the same period in 2020 and 5.95\% higher than Q1, 2021.
By falling into the negative region twice in 2020, the Nigerian economy met the definition of recession. With a positive start of the first quarter of 2021 and $5.01 \%$ growth in Q2, arguably the most robust growth since 2014, the Nigerian economy is hoping to bounce back from the ills of the Corona Virus Disease. African Development Bank predicted that the Nigerian economies will grow by $1.5 \%$ in 2021 and $2.9 \%$ in 2022.

Fiscal Deficit. The government went into budgetary deficit due to a fall in government receipt, resulting from falling oil prices, weak demand for crude oil, low tax revenue, declining yields from government ventures, and increasing demand for medical equipment. The period of COVID-19 increased government roles; the government had to step in to ease the suffering of her citizen and ensure that business did not collapse. These were in the form of reliefs, tax holidays, rent freeze, palliatives, wage support, loans and various grants to households and businesses. The declining revenue made it impossible to fund these services without incurring debts; the government had to borrow. Nigeria was already in a high internal and external debt burden and instabilities before the Corona Virus disease of 2019. Government borrowing had skyrocketed to a level considered threatening to the stability of the Nigerian economy. Author [56] observed that the continuous deficit financing in the economy through the central banks sometimes results in inflationary pressures. A study by [55] revealed that external debt has a significant negative impact on the economic growth in Nigeria. In January 2021, the international rating agency Fitch Ratings warned that continual dependence on central bank lending could undermine the stability of the Nigerian economy.

The Debt Management Office stated that an attempt was to reduce new borrowing due to Nigeria's increasing debt to GDP ratio. In 2017, new borrowing was $\$ 2.36$ trillion, $\$ 2.01$ trillion in 2018, 1.61 in 2019 and was initially placed at \#1.59 trillion in the first appropriation Act of 2020 but was reversed upward due to the COVID-19. It was reversed to $\$ 4.20$ trillion (DMO, 2021). As of 2018, Nigeria's debt was 22.38 trillion, consisting of internal and external borrowing. As of September 2020, the Nigerian debt was estimated at $\$ 13.2$ trillion, representing $8.6 \%$ of GDP. The debt ratio rose to $34.98 \%$ in 2020 from $29.10 \%$ in 2019 . As of the end of 2020 , the debt to GDP ratio was $21.61 \%$, according to Debt Management Office (2021). The fiscal deficit is 
also estimated at 3.6\% of GDP (N5.6 trillion) in the 2021 budget, higher than the $3 \%$ benchmark in the Fiscal Responsibility Act of 2007. As of March 2021, total internal and external debt outstanding was $\$ 54,379.13$ million and $\$ 32,859.99$ million, respectively [57]. According to IMF data, Nigeria's debt to GDP ratio was $29.1 \%$ in 2019 and $34.98 \%$ in 2020 . A prediction by statista.com places the figure to increase to $36.97 \%$ in 2026 . IMF data reviewed that the ratio have been rising since 2011 (17.4\%); $17.6 \%$ in 2012, $18.3 \%$ in $2013,17.5 \%$ in $2014,23.4 \%$ in 2016 and $27.6 \%$ in 2018. The Rising debt burden puts Nigeria's economic sustainability in doubt. Continued debt accumulation has consequences in the burden of repayment and servicing; this is only detrimental to the future generation. It is important to note that borrowing only becomes detrimental if there are not put to good and productive use.

Exchange Rate. As the price of any other commodity, the exchange is the price of a country's currency to the currencies of other countries in the foreign exchange market. Exchange rates are determined mainly by the forces of demand and supply in the market. The central bank often steps in to influence exchange rate positions using some available tools called a managed float exchange rate system. Mostly, the CBN use the excess reserve in controlling the naira position. The implication of using the resources is depletion in reserves. In the absence of the Central Bank's influence, the demand and supply determine the value of a local currency. As the demand for a local currency increases due to the need by foreigners to either invest in a local economy, buy commodities or perform other transactions that will require the exchange to a local currency, the local currency appreciates. This is contrary to depreciation which occurs due to the fall in demand of a currency relative to its supply.

The coronavirus disease brought about a considerable halt in most productive activities at the early stages of the virus. Coexisting with the already depreciated naira at $306.9 / \$$ in 2019 caused by weak demand for naira, the position of the naira only worsened during the early periods of COVID (2020) and 2021 COVID era. For instance, in 2020, the naira depreciated to $358.8 / \$$ from $306.9 / \$$ in 2019 . Even with production and economic activities kick-starting in the economy, the exchange rate continued to decline. As of the 29th of June, 2021, the naira had fallen to as low as $410.83 / \$$ at the investor's window compared to $411.28 / \$$ the previous day. The rate was
$502 / \$$ and $500 / \$$ for the same periods [11]. The website further reported that as of Tuesday, 5th of October, 2021, the naira was trading at $414.3 / \$$ at the investor's window and $575 / \$$ at the parallel market. In a similar market, the naira has been more volatile, depreciating above $575 / \$$ in September 2021. A study by [58] revealed that exchange rate depreciation and money supply are the major causes of inflation in Nigeria. In line with his findings, the depreciated naira value of $358.8 / \$$ in 2020 to $410.83 / \$$ in June 2021 corresponds to $13.25 \%$ and $17.75 \%$ inflation rates in the same periods. As the naira continues to weaken, it becomes costly for producers to import intermediate inputs required for the product. The implication is that domestic and imported commodities have become expensive, as observed in recent months.

\section{CONCLUSIONS}

The Nigerian economy was not prepared to resist or withstand shocks from historical observation. The socio-economic foundation is weak.

These weak socio-economic settings have made the economy vulnerable to external and internal shocks. A single stream of wealth is not enough to sustain a nation. Economic diversification is paramount. The health sector contributes to the stability and prosperity of a nation's economy and thus, should be adequately funded to ensure functionality and meet international best practices. A stable health sector will help mitigate the effects of pandemics and hence, sustain the economy.

Recommendations. A healthy nation is always a wealthy nation. Health is paramount and must be a top priority for Government, NonGovernmental Organizations and individuals. The Nigerian government should provide adequate and internationally standard training facilities for her health workers and ensure that they are paid well when due. The habit of a constant strike by health workers due to the inability of the government to address their needs such as salary increment, provision of hospital equipment, security of health staff some level of autonomy should be addressed for the interest of the nation and health of Nigerians. Healthy Nigerians will produce a healthy socio-economic development. There is a need to fully diversify the economic/productive base in the economy. Alongside achieving economic diversification, there is a 
need to improve the existing agriculturalindustrial link. An improvement in the agricultural sector will imply more available raw materials to industries, reduced imports and less burden on exchange rates. Other sectors should be exploited. Exploration of abundant mineral deposits scattered all over Nigeria should be considered. The ICT sector is rapidly growing in Nigeria that needs more support. Among other sectors, there is a need to improve manufacturing and agricultural value addition; exporting or consuming commodities in their primary form or depending on other nations to add values to our items should be discouraged. They are encouraging and empowering companies (especially domestic companies) that can convert these commodities in Nigeria. The government should scrap out petroleum subsidies and use the monies to build domestic refineries while encouraging privately owned refineries. In the short term, it might increase the already high petroleum prices. However, there will be a significant drop in prices and an increased volume of petroleum products in Nigeria and export in the long term.

The Central Bank should adopt effective monetary policy measures to facilitate credit to private sectors to promote investment in key sectors in the economy. The CBN should adopt lowinterest-rate policies to expand the financial base of the economy; attention should be placed on the most productive sectors. There is a need for an increased stimulus package to all industries and households to sustain and improve employment and consumption levels. There is a need for improved efficiency in government spending. The government should sincerely invest in infrastructures to reduce the cost burden on the pri- vate sector. To stimulate the economy from the COVID-19 backdrop, the government can improve demand by increasing construction and infrastructure. This has a short-term effect of increasing demand, the medium-term impact of improvement private investment and employment in those areas and the long-term effect of improving and sustaining economic growth and development. The government should critically choose its policies not to threaten the existence of foreign direct and portfolio investments in the country. The Nigerian tax rate is one of the lowest globally, yet to sustain and revive already drowning businesses and attract new companies, there is a need for financial/tax and other relief for enterprises. In line with promoting enterprises, the government needs to create a conducive environment for businesses and restore investor confidence; these involve solving the high level of insecurity and providing social overheads and policies that improve competition. There is a crucial need to increase government investment in the health and education sector to prepare the nation for any other health emergency and build its human capital.

Overall, suppose these policies and more diversification policies are put in place. In that case, Nigeria should be able to adequately feed itself (relying less on import) while also improving the export sector, balance of payment positions, exchange rate position, reduced inflation rates, improved employment rate, improved on human capital development with significant investment in health and education sectors enough to achieve enhanced performance in these sectors and lastly, achieve sustainable development.

\section{REFERENCES}

1. Abdulkareem, A., \& Abdulhakeem, K. (2016). Analysing oil price-macro economy volatility in Nigeria. CBNJournal of Applied Statistics, 7(1), 1-22.

2. Adams, O. O., Chime, C. C., Abu, S. O., \& Aigomududu, E. E (2010). How to make public spending propoor in Nigeria. Policy brief. Canada: Poverty and Economic Policy Network.

3. African Development Bank Group. (2021). Nigeria Economic Outlook. Retrieved from https://www.afdb.org/en/countries-west-africa-nigeria/nigeria-economicoutlook\#: :text=Recent\%20macroeconomic\%20and\%20financial\%20developments\&text=0v erall\%20real\%20GDP\%20is\%20estimated,decline\%20from\%20being\%20much\%20worse

4. Ajisegiri, W. S., Odusanya, O. 0., \& Joshi, R. (2020). COVID-19 Outbreak Situation in Nigeria and the Need for Effective Engagement of Community Health Workers for Epidemic Response. Global Biosecurity, 1(4). doi: 10.31646/gbio.69 
5. Alege, S. O., Adamu, M., \& Muhammad, S. A. (2014). Effects Of corruption on economic development in Nigeria. Global Journal of Interdisciplinary Social Sciences, 3(3), 209-215.

6. Soto, A. (2021, 15 June). Surging inflation in Nigeria fuels crime wave, says World Bank. Retrieved from https://www.aljazeera.com/economy/2021/6/15/surging-inflation-in-nigeria-is-fuelingcrime-wave-world-bank

7. Rajkumar, A. S., \& Swaroop, V. (2008). Public spending and outcomes: Does governance matter? Journal of Development Economics, 86(1), 96-111. doi: 10.1016/j.jdeveco.2007.08.003

8. Andriyani, K., Marwa, T., Adnan, N., \& Muizzuddin, M. (2020). The Determinants of Foreign Exchange Reserves: Evidence from Indonesia. The Journal of Asian Finance, Economics and Business, 7(11), 629-636. doi: 10.13106/jafeb.2020.vol7.no11.629

9. Jegede, A. S. (2007). What Led to the Nigerian Boycott of the Polio Vaccination Campaign? PLoS Medicine, 4(3), e73. doi: 10.1371/journal.pmed.0040073

10. Central Bank Nigeria. (2021). Nigeria's Inflation rates. Retrieved from https://www.cbn.gov.ng/rates/inflrates.asp?year=2021

11. Oyekanmi, S. (2021, June 30). Exchange rate gains at official window as dollar supply increases significantly by $115 \%$. Retrieved from https://nairametrics.com/2021/06/30/exchange-rategains-at-official-window-as-dollar-supply-increases-significantly-by-115/

12. Food and Agriculture Organization of the United Nations. (2019). The state of food security and nutrition in the world 2019. Retrieved from https://www.fao.org/3/ca5162en/ca5162en.pdf

13. Filmer, D., Hammer, J. S., \& Pritchett, L. H. (2000). Weak Links in the Chain: A Diagnosis of Health Policy in Poor Countries. The World Bank Research Observer, 15(2), 199-224. doi: 10.1093/wbro/15.2.199

14. Gilbert, M., Pullano, G., Pinotti, F., Valdano, E., Poletto, C., Boëlle, P.-Y., ... Colizza, V. (2020). Preparedness and vulnerability of African countries against importations of COVID-19: a modelling study. The Lancet, 395(10227), 871-877. doi: 10.1016/s0140-6736(20)30411-6

15. World Health Organization. (2021). Global technical strategy for malaria 2016-2030. 2021 update. Retrieved from https://www.who.int/publications/i/item/9789240031357

16. Haacker, M. (2004). The Macroeconomics of HIV/AIDS. doi: 10.5089/9781589063600.071

17. Inegbedion, H. (2021). Impact of COVID-19 on economic growth in Nigeria: opinions and attitudes. Heliyon, 7(5), e06943. doi: 10.1016/j.heliyon.2021.e06943

18. Ilesanmi, O., \& Afolabi, A. (2020). Perception and practices during the COVID-19 pandemic in an urban community in Nigeria: a cross-sectional study. PeerJ, 8, e10038. doi: 10.7717/peerj.10038

19. International Monetary Fund. (2007, January). Revision of the Fifth Edition of the IMF's Balance of Payments Manual. Retrieved from https://www.imf.org/external/np/sta/bop/bopman5.htm

20. UNAIDS. (2021). FactSheet. Global HIV Statistics. Retreieved from http://www.unaids.org/sites/default/files/media_asset/UNAIDS_FactSheet_en.pdf

21. Gylych, J., Ahmad Jibrin, A., Celik, B., \& Isik, A. (2020). Impact of Oil Price Fluctuation on the Economy of Nigeria, the Core Analysis for Energy Producing Countries. Global Market and Global Trade [Working Title]. doi: 10.5772/intechopen.94055

22. Liu, Y., Ning, Z., Chen, Y., Guo, M., Liu, Y., Gali, N. K., ... Lan, K. (2020). Aerodynamic analysis of SARSCoV-2 in two Wuhan hospitals. Nature, 582(7813), 557-560. doi: 10.1038/s41586-020-2271-3

23. Habib, M. A., Dayyab, F. M., Iliyasu, G., \& Habib, A. G. (2021). Knowledge, attitude and practice survey of COVID-19 pandemic in Northern Nigeria. PLOS ONE, 16(1), e0245176. doi: 10.1371/journal.pone.0245176

24. McKibbin, W., \& Sidorenko, A. (2006). Global macroeconomic consequences of pandemic Influenza. Retrieved from https://cama.crawford.anu.edu.au/pdf/working-papers/2006/262006.pdf 
25. Mordi, Ch., Englama, A., \& Adebusuyi, B. (2010). The changing structure of the Nigerian economy. Retrieved from https://www.cbn.gov.ng/out/2011/pressrelease/gvd/the\%20changing\%20structure $\% 20$ of $\%$ 20the\%20nigerian\%20economy\%20second\%20edition.pdf

26. Mustapha, J., Adedokun, K., \& Nasir, I. (2020). Public health preparedness towards COVID-19 outbreak in Nigeria. Asian Pacific Journal of Tropical Medicine, 13(5), 197. doi: 10.4103/19957645.279650

27. News24. (2004, February 11). Vaccine boycott spreads polio. Retrieved from https://www.news24.com/News24/Vaccine-boycott-spreads-polio-20040211

28. Nigeria Centre for Disease Control. (2021). COVID-19 Outbreak In Nigeria Situation Report. https://ncdc.gov.ng/diseases/sitreps/?cat=14\&name=An\%20in\%20Nigeria

29. Nigeria Health Watch. (2021, April 28). Will you take the COVID-19 Vaccine? A Household Survey on the Perception of Nigerians towards a COVID-19 vaccine. Retrieved from https://nigeriahealthwatch.com/will-you-take-the-covid-19-vaccine-a-household-survey-onthe-perception-of-nigerians-towards-a-covid-19-vaccine/

30. Njunda, A. L., Njumkeng, C., Nsagha, S. D., Assob, J. C. N., \& Kwenti, T. E. (2016). The prevalence of malaria in people living with HIV in Yaounde, Cameroon. BMC Public Health, 16(1). doi: 10.1186/s12889-016-3647-z

31. Ochigbo, F. (2012). Nigeria's agriculture budget under 10\%. The Nation newspaper.

32. Ndimele, P. (2017). The Political Ecology of Oil and Gas Activities in the Nigerian Aquatic Ecosystem. Retrieved from https://www.elsevier.com/books/the-political-ecology-of-oil-and-gas-activitiesin-the-nigerian-aquatic-ecosystem/ndimele/978-0-12-809399-3

33. Olapegba, P. O., Ayandele, Kolawole, S., Oguntayo, R., Gandi, J., Dangiwa, A., \& Ottu, I., \& Iorfa, S. (2020). COVID-19 knowledge and perception in Nigeria. doi: https://psyarxiv.com/j356x/

34. Akwaowo, C., Eyo, C., Umoh, I., Ekpin, V., \& Esubok, N. (2021). Perception and practices towards Covid-19 amongst residents in Southern Nigeria. Nigerian Postgraduate Medical Journal, 28(3), 149. doi: 10.4103/npmj.npmj_554_21

35. Chris, O., Amujiri, B., \& Ndibe, N. (2015). Diversification of the economy: A panacea for Nigerian economic development. International Journal of Multidisciplinary Research and Development, 2(5), 477-483.

36. Oyinbo, O., Zakari, A. \& Rekwot, G. (2013). Agricultural budgetary allocation and economic growth in Nigeria: Implications for agricultural transformation in Nigeria. Consilience: The Journal of Sustainable Development, 10(1), 16-27.

37. Akanmidu, P. (2015). A historical perspective of petroleum on Nigeria's economic crisis since independence. Global Journal of Human-Social Science, 15(2), 17-24.

38. PWC. (2016). Transforming Nigeria's agricultural value chain. Retrieved from https://www.pwc.com/ng/en/assets/pdf/transforming-nigeria-s-agric-value-chain.pdf

39. Dada, S., Oniya, O., \& Hussain, O. (2020). COVID-19 pandemic: Nigerians' perception about the national health system and socio-political rights. International Journal of Research in Medical Sciences, 8(12), 4174. doi: 10.18203/2320-6012.ijrms20205284

40. Tran, T. V., \& Le, T. (2020). Optimum Reserves in Vietnam Based on the Approach of Cost-Benefit for Holding Reserves and Sovereign Risk. The Journal of Asian Finance, Economics and Business, 7(3), 157-165. doi: 10.13106/jafeb.2020.vol7.no3.157

41. Ubong, E., \& Godwin, E. (2020). Public health expenditure and the quality of life in Nigeria: An empirical investigation. International Journal of Research and Sustainable Development, 7(1), 3551. 
42. United Nations Sevelopment Programme. (2021). Human Development Report. Retrieved from http://hdr.undp.org/en/content/2021-22-hdr-theme-announcement

43. United Nations. Economic Comission for Africa. (2012). Economic report on Africa: Unleashing Africa's potential as a pole of Global Growth. Retrieved from https://repository.uneca.org/handle/10855/21725

44. Van Doremalen, N., Bushmaker, T., Morris, D. H., Holbrook, M. G., Gamble, A., Williamson, B. N., ... Munster, V. J. (2020). Aerosol and Surface Stability of SARS-CoV-2 as Compared with SARS-CoV1. New England Journal of Medicine, 382(16), 1564-1567. doi: 10.1056/nejmc2004973

45. UNECA. (2020, April 17). ECA. The economic impact of COVID-19 on African cities likely to be acute through a sharp decline in productivity, jobs \& revenues. Retrieved from https://www.un.org/africarenewal/news/coronavirus/eca-economic-impact-covid-19-africancities-likely-be-acute-through-sharp-decline-productivity

46. Warwick, Mc., \& Roshen, F. (2020). The Global Macroeconomic Impacts of COVID-19: Seven Scenarios. Retrieved from https://www.brookings.edu/wpcontent/uploads/2020/03/20200302_COVID19.pdf

47. The World Bank. (2020). Hospital beds (per 1000 people) - Nigeria. Retrieved from https://data.worldbank.org/indicator/SH.MED.BEDS.ZS?locations=NG

48. World Health Organization. (2017). World malaria report 2017. Geneva: WHO.

49. World Health Organization. (2021). R\&D. Blueprint and COVID-19. Retrieved from https://www.who.int/teams/blueprint/covid-19

50. World Health Organization. (2020, January 31). WHO ramps up preparedness for novel coronavirus in the African region. Retrieved from https://www.afro.who.int/news/who-rampspreparedness-novel-coronavirus-african-region

51. Shang, Y., Li, H., \& Zhang, R. (2021). Effects of Pandemic Outbreak on Economies: Evidence From Business History Context. Frontiers in Public Health, 9. doi: 10.3389/fpubh.2021.632043

52. Maryla, M., Aaditya, V. D. (2020). The potential impact of COVID-19 on GDP and Trade: A preliminary assessment. Retrieved from https://openknowledge.worldbank.org/handle/10986/33605

53. Transparency International. (2020). Corruption Perception Index. Retrieved from www.transparency.org/en/cpi/2020/index

54. The World Bank. (2020). World Development Indicators. Retrieved from https://databank.worldbank.org/source/world-development-indicators

55. Nwanna, I. O., Nkiruka, U. (2019). Deficit financing and economic growth: the Nigerian experience. International Journal of Economics and Financial Management, 4(1), 28-49.

56. Ojong, C. M., Owui, H., Effiong, Ch. (2013). Effect of budget deficit financing on economic development of the Nigerian economy: 1980-2008. European Journal of Business and Management, 5(3), 61-84.

57. Debt Management Office Nigeria. (2021). Total public debts. Retrieved from https://www.dmo.gov.ng/debt-profile/total-public-debt

58. Samuel, U., Israel, V., Chibuzor, B., \& Quansah, J. (2021). Relationship Between Inflation and Unemployment: Testing Philips Curve Hypotheses and Investigating the Causes of Inflation and Unemployment in Nigeria. Path of Science, 7(9), 1013-1027. doi: 10.22178/pos.74-13

59. Orjinmo, N. (2021). Why Nigerian looters are targeting Covid-19 aid. Retrieved from https://www.bbc.com/news/world-africa-54695568

60. Dabang, P., \& Ukomadu, A. (2020, November). In Nigeria, looters target government warehouses stocked with COVID-19 relief. Retrieved https://www.reuters.com/article/uk-healthcoronavirus-nigeria-food-idUKKBN27P0YZ 
61. Organisation of Economic Cooperation and Development. (2020). Evaluating the initial impact of COVID-19 containment measures on economic activity. Retrieved from https://www.oecd.org/coronavirus/policy-responses/evaluating-the-initial-impact-of-covid19-containment-measures-on-economic-activity-b1f6b68b/

62. Gylych, J., Jbrin, A. A., Celik, B., \& Isik, A. (2020). The effect of oil price fluctuation on the economy of nigeria. International Journal of Energy Economics and Policy, 10(5), 461-468. doi: 10.32479/ijeep.9493

63. Chukwuma, M., \& Adaku, O. (2019). Nigeria's health sector performance trailed behind other countries in 2019. Retrieved from www.guardian.ng/features/health/nigerias-health-sectorperformance-trailed-behind-other-countries-in-2019/ 